\title{
Pushover Analysis of G+3 Reinforced Concrete Building with soft storey
}

\author{
Akshay V. Raut ${ }^{1}$, Prof. RVRK Prasad ${ }^{2}$ \\ ${ }^{I} M$-Tech student of civil Engg. Department, K.D.K.C.E \\ ${ }^{2}$ Professor of civil Engg. Department, K.D.K.C.E.
}

\begin{abstract}
Many urban multistorey buildings in India today have open first storey as an unavoidable feature. This is primarily being adopted to accommodate parking or reception lobbies in the first storey. This paper highlights the importance of explicitly recognizing the presence of the open first storey in the analysis of the building and also for immediate measures to prevent the indiscriminate use of soft first storeys in buildings. Alternate measures, involving stiffness balance of the open first storey and the storey above, are proposed to reduce the irregularity introduced by the open first storey. The structural engineering profession has been using the nonlinear static procedure (NSP) or pushover analysis. Modeling for such analysis requires the determination of the nonlinear properties of each component in the structure, quantified by strength and deformation capacities, which depend on the modeling assumptions. Pushover analysis is carried out for either user-defined nonlinear hinge properties or default-hinge properties, available in some programs based on the FEMA-356 and ATC-40 guidelines. This paper aims to evaluate the zone -II selected reinforced concrete building to conduct the non-linear static analysis (Pushover Analysis). The pushover analysis shows the pushover curves, capacity spectrum, plastic hinges and performance level of the building. This non-linear static analysis gives better understanding and more accurate seismic performance of buildings of the damage or failure element.
\end{abstract}

Keywords: multistorey buildings, open first storey, performance of buildings, Pushover analysis

\section{Introduction}

The pushover analysis is a method to observe the successive damage states of a building. The method is relatively simple to be implemented, and provides information on strength, deformation and ductility of the structure and distribution of demands which help in identifying the critical members likely to reach limit states during the earthquake and hence proper attention can be given while designing and detailing. This method assumes a set of incremental lateral load over the height of the structure. Local nonlinear effects are modelled and the structure is pushed until a collapse mechanism is developed. With the increase in the magnitude of loads, weak links and failure modes of the buildings are found. At each step, the base shear and the roof displacement can be plotted to generate the pushover curve .This method is relatively simple and provides information on the strength, deformation and ductility of the structure and distribution of demands. This permits to identify the critical members likely to reach limit states during the earthquake by the formation of plastic hinges. On the building frame load/displacement is applied incrementally, the formation of plastic hinges, stiffness degradation, and lateral inelastic force versus displacement response for the structure is analytically computed.

To perform a pushover analysis, a lateral load versus deformation curves for the member is required. The results from a pushover analysis will give the load versus deformation curves. Moreover, the pushover analysis gives only curve of the base shear versus roof displacement behavior of a building. The actual performance of a building may differ from the calculated performance, since the load versus deformation curves and the earthquake levels used in the analysis are estimates.

The structural engineering profession has been using the nonlinear static procedure (NSP) or pushover analysis described in FEMA-356 and ATC-40, when pushover analysis is used carefully it provides useful information that cannot be obtained by linear static or dynamic analysis procedure.

\subsection{Research Significance}

\section{Pushover analysis of structure}

The present study is to evaluate the behavior of $\mathrm{G}+3$ reinforced concrete frame structure subjected to earthquake forces in zone II. The reinforced concrete structures are analyzed by nonlinear static analysis (Pushover Analysis) using SAP2000 software. It shows the performance levels, behavior of the components and failure mechanism in a building. It also shows the types of hinge formation, the strength and capacity of the weakest components. 


\subsection{Performance Based Design for Nonlinear Static Pushover Analysis}

Create the basic computer model of four storey building frame structure. Define properties and acceptance criteria for the pushover hinges .The program includes several built-in default hinge properties that are based on average values from ATC-40 for concrete members and average values from FEMA-356 for steel members. These built in properties can be useful for preliminary analyses, but user defined properties are recommended for final analyses. Locate the pushover hinges on the model by selecting one or more frame members and assigning them one or more hinge properties. Define the pushover load cases. Pushover load case is used to apply gravity load and then lateral pushover load cases are specified to start from the final conditions of the gravity pushover. Pushover load cases can be force controlled, that is, pushed to a certain defined force level, or they can be displacement controlled, that is, pushed to a specified displacement.

The numbers of hinges are shown in the fig. 1 and fig. 2 In each member showing the hinges in beams the immediate occupancy, life safety, collapse prevention and some limited hinges are shown in column to define the force deflection behavior of the hinge. The lateral load is applied on the frame, which when deflected forms hinges. Frame is estimating the plastic hinge formation at the yielding and significant difference in the hinging patterns at the ultimate state. The hinge locations are shown in the frame. In frame hinges shows a ductile beam mechanism in which the columns are stronger than the beam. Damage or failure occurs at the beam.

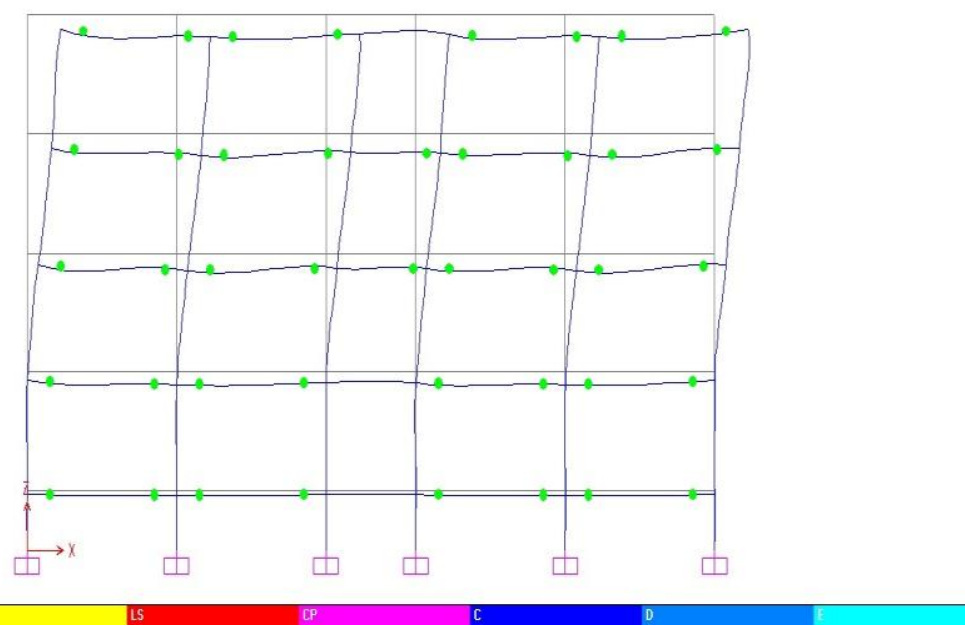

Fig.1 Showing hinge model at yielding

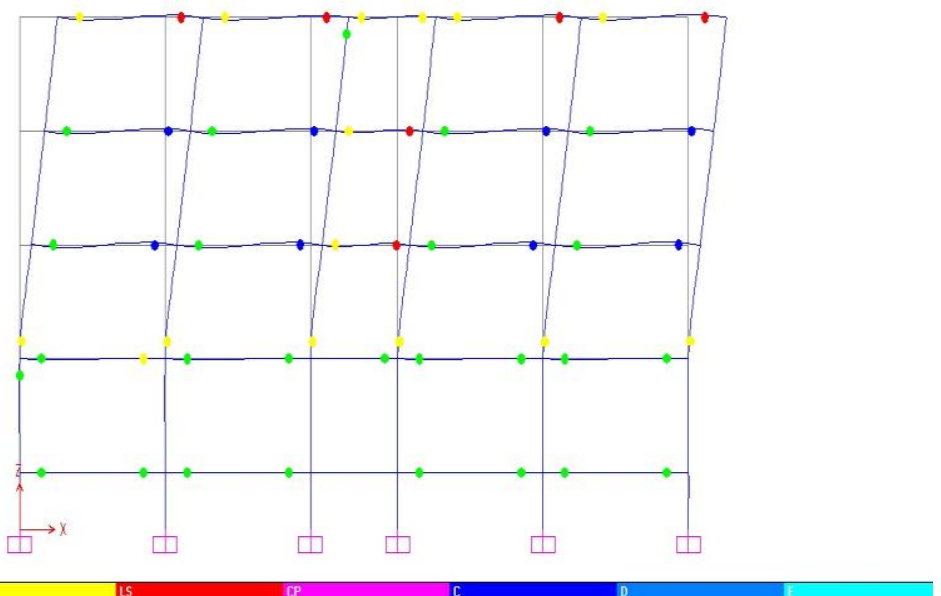

Fig.2 Showing Hinge Model at ultimate State 


\begin{tabular}{|c|c|c|c|c|c|c|c|c|c|c|c|}
\hline \multicolumn{10}{|c|}{ Table-1 : Plastic Hinge Pattern for Pushover Analysis at Different Damage level } \\
\hline $\begin{array}{c}\text { Step } \\
\text { s }\end{array}$ & $\begin{array}{c}\text { Displaceme } \\
\text { nt }\end{array}$ & $\begin{array}{c}\text { BaseFor } \\
\mathbf{c e}\end{array}$ & $\begin{array}{c}\text { Ato } \\
\text { B }\end{array}$ & $\begin{array}{c}\text { Btol } \\
\mathbf{O}\end{array}$ & $\begin{array}{c}\text { IOtoL } \\
\text { S }\end{array}$ & $\begin{array}{c}\text { LStoC } \\
\mathbf{P}\end{array}$ & $\begin{array}{c}\mathbf{C P t o} \\
\mathbf{C}\end{array}$ & $\begin{array}{c}\text { Cto } \\
\mathbf{D}\end{array}$ & $\begin{array}{c}\text { Dto } \\
\mathbf{E}\end{array}$ & $\begin{array}{c}\text { Beyond } \\
\mathbf{E}\end{array}$ & $\begin{array}{c}\text { Tota } \\
\mathbf{I}\end{array}$ \\
\hline & $\mathrm{mm}$ & $\mathrm{KN}$ & & & & & & & & & \\
\hline 0 & 0 & 0 & 364 & 256 & 0 & 0 & 0 & 0 & 0 & 0 & 620 \\
\hline 1 & 2.795879 & 81.687 & 360 & 260 & 0 & 0 & 0 & 0 & 0 & 0 & 620 \\
\hline 2 & 49.740724 & 813.026 & 306 & 292 & 22 & 0 & 0 & 0 & 0 & 0 & 620 \\
\hline 3 & 55.938982 & 861.205 & 294 & 298 & 28 & 0 & 0 & 0 & 0 & 0 & 620 \\
\hline 4 & 57.507663 & 868.578 & 290 & 300 & 30 & 0 & 0 & 0 & 0 & 0 & 620 \\
\hline 5 & 59.451321 & 873.907 & 288 & 300 & 32 & 0 & 0 & 0 & 0 & 0 & 620 \\
\hline 6 & 84.639029 & 897.959 & 286 & 288 & 46 & 0 & 0 & 0 & 0 & 0 & 620 \\
\hline 7 & 165.063103 & 939.347 & 282 & 226 & 70 & 24 & 0 & 18 & 0 & 0 & 620 \\
\hline 8 & 209.54516 & 951.649 & 282 & 206 & 42 & 48 & 0 & 42 & 0 & 0 & 620 \\
\hline 9 & 220.128498 & 953.261 & 282 & 206 & 36 & 48 & 0 & 48 & 0 & 0 & 620 \\
\hline 10 & 223.429769 & 953.583 & 282 & 206 & 36 & 42 & 0 & 54 & 0 & 0 & 620 \\
\hline 11 & 231.041725 & 953.903 & 282 & 206 & 32 & 42 & 0 & 58 & 0 & 0 & 620 \\
\hline 12 & 233.292956 & 953.784 & 282 & 206 & 32 & 36 & 0 & 64 & 0 & 0 & 620 \\
\hline 13 & 237.085457 & 952.983 & 282 & 206 & 32 & 26 & 0 & 74 & 0 & 0 & 620 \\
\hline 14 & 240.655753 & 951.786 & 282 & 206 & 32 & 18 & 2 & 80 & 0 & 0 & 620 \\
\hline
\end{tabular}

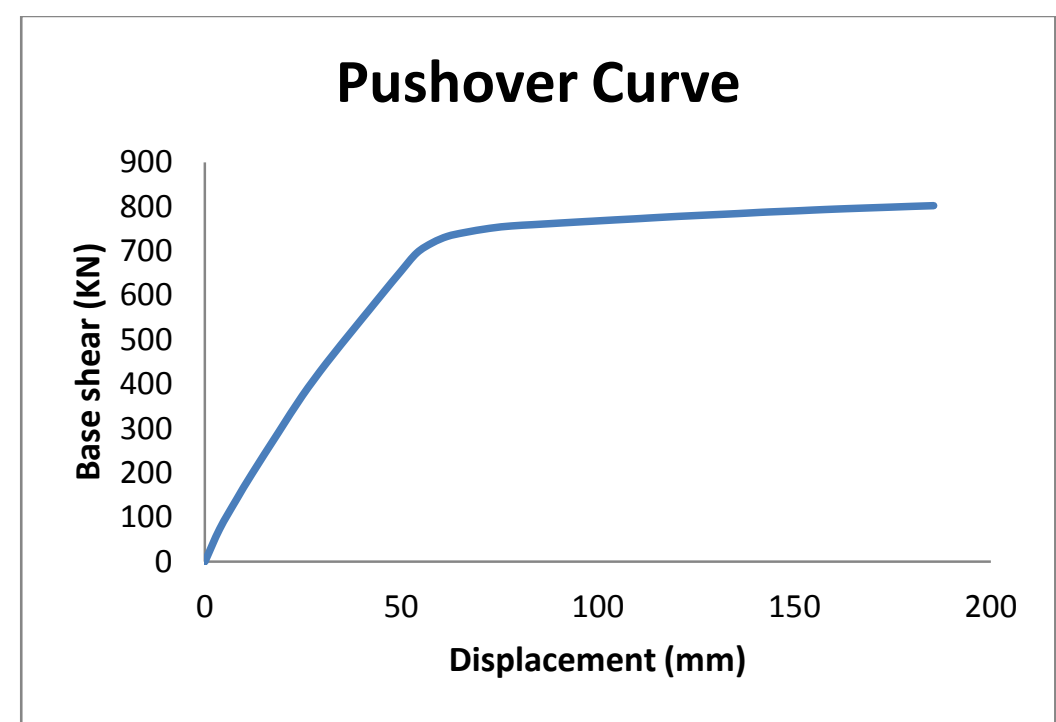

Fig 2. Showing Pushover curve of a building for four storey II zone

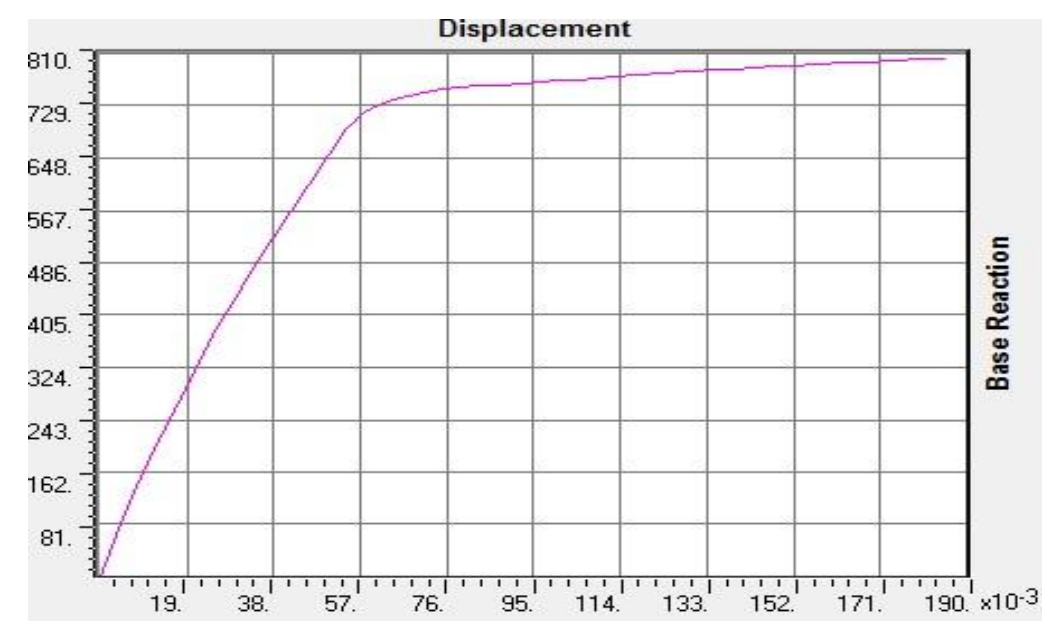

Figure 3. Showing Pushover Curve of a without infill wall frame in $\mathrm{X}$ direction 


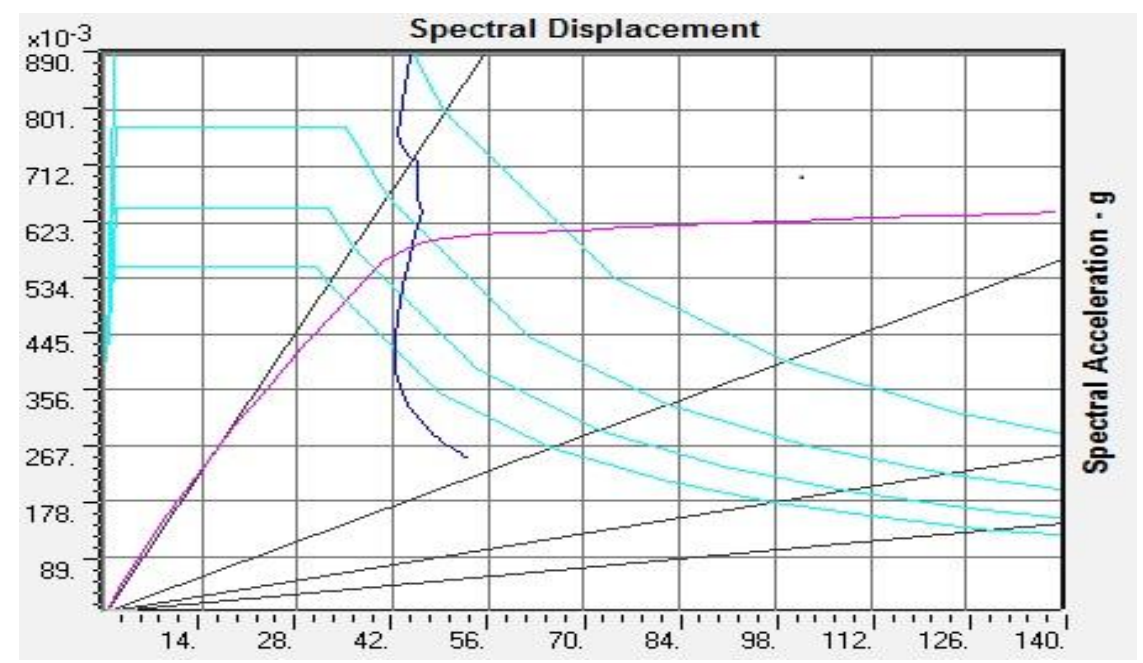

Figure 4. Showing capacity Spectrum

\subsection{Pushover Methodology :-}

Pushover analysis is a static, nonlinear procedure in which the magnitude of the lateral force is incrementally increased, maintaining the predefined distribution pattern along the height of the building. With the increase in the magnitude of the loads, weak links and failure modes of the building are found. Pushover analysis can determine the behavior of a building, including the ultimate load and the maximum inelastic deflection. Local Nonlinear effects are modeled and the structure is pushed until a collapse mechanism gets developed. At each step, the base shear and the roof displacement can be plotted to generate the pushover curve. It gives an idea of the maximum base shear that the structure was capable of resisting at the time of the earthquake. For regular buildings, it can also give a rough idea about the global stiffness of the building.

\subsection{Nonlinear Plastic Hinges Properties :-}

The building has to be modeled to carry out nonlinear static pushover analysis. This requires the development of the force - deformation curve for the critical sections of beams, columns. The force deformation curves in flexure were obtained from the reinforcement details and were assigned for all the beams and columns. The Nonlinear properties of beams and columns have been evaluated using the section designer and have been assigned to the computer model in SAP2000. The flexural default hinges (M3) and shear hinges (V2) were assigned to the beams at two ends. The interacting (P-M2-M3) frame hinges type a coupled hinge property was also assigned for all the columns at upper and lower ends .

\section{Performance level of a structure :-}

The structural and non- structural components of the buildings together comprise the building performance. The performance levels are the discrete damage states identified from a continuous spectrum of possible damage states. The structural performance levels based on the roof drifts are as follows:

Five points labeled A, B, C, D and E are used to define the force deflection behavior of the hinge and these points labeled as

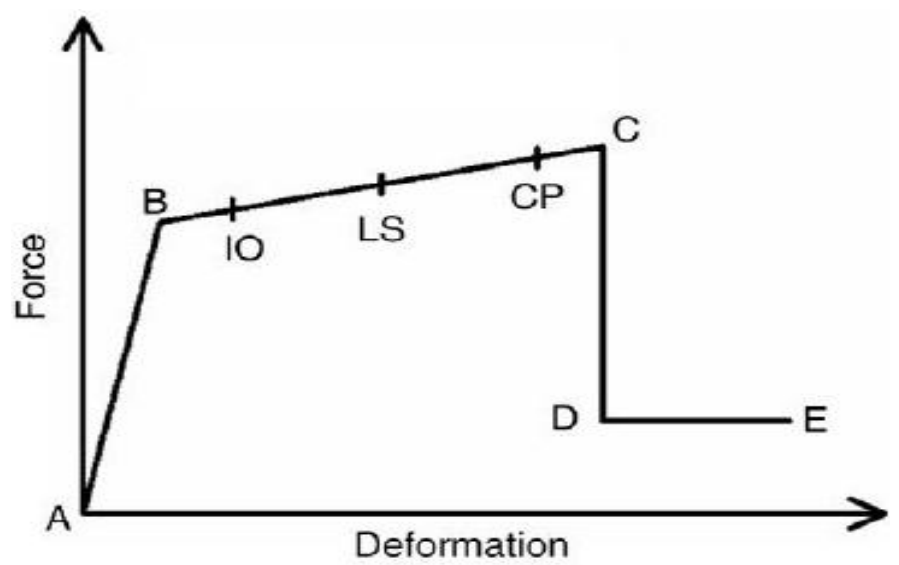

Fig.5 showing Force Vs deformation curve 
The performance levels (IO, LS, and CP) of a structural element are represented in the load versus deformation curve as shown below,

1. A to B - Elastic state,

i) Point 'A' corresponds to the unloaded condition.

ii) Point ' $\mathrm{B}$ ' corresponds to the onset of yielding.

2. B to IO- below immediate occupancy,

3. IO to LS - between immediate occupancy and life safety,

4. LS to CP- between life safety to collapse prevention,

5. $\mathrm{CP}$ to $\mathrm{C}-$ between collapse prevention and ultimate capacity,

i) Point ' $\mathrm{C}$ ' corresponds to the ultimate strength

6. C to D- between $\mathrm{C}$ and residual strength,

i) Point ' $D$ ' corresponds to the residual strength

7. D to E- between D and collapse

i) Point 'E' corresponds to the collapse.

\section{Result and Discussion :-}

A Four storied reinforced concrete frame structure of building was taken to analysis. The frame was subjected to design earthquake forces as specified in the IS code for zone II along longer directions. Bare frame pushover curves for the building in X directions as shown in Figure 2. These curves show the behavior of the frame in terms of its stiffness and ductility. For bare frame maximum base shear from pushover analysis is $951.78 \mathrm{KN}$ and maximum displacement of $240.65 \mathrm{~mm}$ in $\mathrm{X}$ direction. Capacity spectrum is the capacity curve spectral acceleration Vs spectral displacement ( $\mathrm{Sa}$ Vs Sd) co-ordinates. The performance point is obtained by superimposing demand spectrum on capacity curve transformed into spectral coordinates. The frame shows the performance of the on the spectral acceleration corresponding to the performance point. The performance point is obtained at a base shear level of $550 \mathrm{KN}$ and displacement of $45 \mathrm{~mm}$ in the $\mathrm{X}$ direction.

\section{Conclusion}

The pushover analysis is a simple way to explore the nonlinear behavior of the buildings. The results obtained in terms of pushover demand, capacity spectrum and plastic hinges the real behavior of structures. In a four storey building seismic zone -II is designed and constructed using IS-456-1978 and the revised code IS1893- 2000 provisions. Hinges have developed in the beams and columns showing the three stages immediate occupancy, Life safety, Collapse prevention. The column hinges have limited the damage.

\section{References}

[1] A. Vijayakumar, D. L. Venkatesh Babu, " Pushover Analysis of Existing Reinforced Concrete Framed Structures", European Journal of Scientific Research, Vol.71, pp. 195-202,1988.

[2] Ashraf Habibullah, S.E., and Stephen Pyle, S.E," Practical Three Dimensional Nonlinear Static Pushover Analysis", Structure Magazine 1988.

[3] Young J. Park, Anderi M. Reinhorn and Kunnati , "Seismic Damage of Reinforced Concrete Buildings", Proceeding of Ninth World Conference on Earthquake Engineering, Vol.VII, pp. 211-216, 1988.

[4] N. Lakshmanan, "Seismic Evaluation and Retrofitting of Buildings and Structures", ISET Journal of Earthquake Technology,Vol. 43, pp. 31-48, 2006.

[5] Mehmet Inel, Hayri Baytan Ozmen, M. Inel, H.B. Ozmen / Engineering Structures,"Effects of Plastic Hinge Properties in Nonlinear Analysis of Reinforced Concrete Buildings", pp. 1494-1502, 2006.

[6] Z. W. Miao, X. Z. Lu, J. J. Jiang, L. P. Ye, ”Nonlinear fee Model for RCC Shear Walls Based on Multi-Layer Shell Element and Microplane Constitutive Model”, Computational Methods in Engineering and Science Epmesc X ,pp. 1-8,2006.

[7] Kasım Armagan Korkmaz, Fuat Dem_R and Mustafa S_VR ," Earthquake Assessment of R/C Structures with Masonry Infill Walls",International Journal of Science \& Technology, Vol. 2, pp. 155-164, 2007.

[8] Jaegyun Park, Chul-Hun Chung, Chang Hun Hyun, Yong Lak Paek, Kang Ryong Choi , "Static and Dynamic Analysis of a Concrete Shear-Wall", pp. 1-7, 2007.

[9] Chung- Yue Wang and Shaing-Yung Ho," Pushover Analysis for Structure Containing RC Walls", The 2nd International Conference on Urban Disaster Reduction, Taipei, Taiwan, pp. 1-8, 2007.

[10] S.A. Anagnostopoulos and C.E. Karamaneas," Collision Shear Walls to Mitigate Seismic Pounding of Adjacent Buildings", The $14^{\text {th }}$ World Conference on Earthquake Engineering, pp. 1-8, 2008.

[11] Y.M. Fahjan, J. Kubin \& M.T. Tan ," Nonlinear Analysis Methods for Reinforced Concrete Buildings with Shear Walls", pp. 18,2010 .

[12] Romy Mohan, C Prabha ," Dynamic Analysis of RCC Buildings with Shear Wall”, International Journal of Earth Sciences and Engineering, Vol. 04, pp. 659-662,2011. 